\title{
Strategi Pengembangan Desa Ekowisata Pampang untuk Meningkatkan Jumlah Kunjungan Wisatawan
}

\author{
Kartika Fajar Nieamah ${ }^{1)}$, Noviana Utami ${ }^{2)}$, Arief Fiddienika ${ }^{3)}$, Yitno Purwoko ${ }^{4)}$ \\ DI-Pramugari-Pramugara ${ }^{5}$ \\ Sekolah Tinggi Teknologi Kedirgantaraan Yogyakarta ${ }^{1,2,3)}$, STIE Pariwisata API Yogyakarta ${ }^{4)}$ \\ E-mail : kartika.nieamah@gmail.com ${ }^{1)}$, noviana.utami@gmail.com ${ }^{2)}$, Arief.fiddienika@gmail.com ${ }^{3)}$, \\ yitno.purwoko@gmail.com ${ }^{4)}$
}

\begin{abstract}
The purpose of this research is to identify: the development strategy of Pampang tourist villages, the implementation of the development strategies that have been implemented, and the impact of strategies that have been implemented in the tourist village. The research method used is descriptive qualitative method. Data is collected through document analysis, observation, and interviews. The analysis technique used is data reduction with a form of analysis that sharpens, classifies, directs, discards unnecessary and organizes in such a way that final conclusions can be drawn. The resultvof the analysis show an increase in the number of visits due to unspoiled objects, good accessibility and very affordable package prices. It is necessary to increase the skill of human resources, especially there are job opportunities for citizents and opportunities for increasing the number of tourist
\end{abstract}

Keywords: Strategi, development, Tourism Village.

Abstrak - Gunungkidul merupakan salah satu kabupaten di Yogykarta yang memiliki potensi desa wisata sangat bagus. Tujuan dari penelinian ini adalah mengidentifikasi strategi pengembangan desa Ekowisata Pampang, mengidentifikasi implementasi strategi pengembangan yang telah diterapkan, mengidentifikasi dampak strategi yang sudah dijalankan di Desa Ekowisata Pampang. Metode penelitian yang digunakan adalah metode deskriptif kualitatif. Data yang dikumpulkan melalui: analisis dokumen, observasi, dan wawancara. Teknik analisis yang digunakan adalah reduksi data dengan bentuk analisis yang menajamkan, menggolongkan, mengarahkan, membuang yang tidak perlu dan mengorganisasikan data sedemikian rupa sehingga dapat ditarik kesimpulan akhir. Hasil penelitian ini adalah pengembangan potensi wisata harus terus ditingkatkan. Hal ini dikarenakan desa wisata di Gunungkidul memiliki potensi alam sehingga perawatan icon wisata harus benar-benar diperhatikan. Berikut adalah hasil dari analisis meunjukkan bahwa kelebihan desa wisata ini adalah peningkatan jumlah kunjungan dikarenakan objek yang masih alami, aksesibilitas yang baik dan harga paket yang sangat terjangkau. Kelemahan adalah perlunya peningkatan keterampilan SDM. Peluang adalah memberikan banyak pekerjaan untuk warganya sehingga sadar wisata dan peluang peningkatan jumlah wisatawan. Ancaman adalah ancaman bencana alam seperti, banjir, longsor, dan gempa bumi.

\section{Kata Kunci : Strategi, Pengembangan, Desa Ekowisata Pampang}

\subsection{Latar Belakang}

Pariwisata merupakan sektor yang penting dalam pertumbuhan perekonomian Indonesia. Pariwisata merupakan bagian yang tidak terpisahkan dari kehidupan manusia terutama menyangkut kegiatan sosial dan ekonomi. Kekayaan alam dan atraksi-atraksi lainnya adalah hal yang sangat penting dalam pariwisata Indonesia. Pariwisata merupakan sebuah aktivitas atau kegiatan yang kini telah menjadi bagian dari kehidupan masyarakat di dunia.

$\mathrm{Di}$ Indonesia, Yogyakarta merupakan salah satu provinsi yang menjadi tujuan wisata baik wisatawan domestik maupun mancanegara. Hal ini disebabkan karena Yogyakarta menawarkan berbagai macam jenis wisata, diantaranya adalah wisata alam, wisata buatan, wisata kuliner, wisata budaya dan sejarah, serta wisata belanja. Saat ini, objek wisata yang tengah mengalami kemajuan adalah wisata alam.

Wisata alam yang ada di Yogyakarta adalah pantai, pegunungan, sungai, bentangan sawah, serta susur sungai di dalam goa. Wisata Alam Yogyakarta popular dengan keindahan alam di pedesaan. Salah satu kabupaten yang terkenal dengan wisata alamnya di Yogyakarta adalah Gunung Kidul.

Desa ekowisata Pampang merupakan objek wisata dari, oleh, dan untuk rakyat. Masyarakat setempat mengelola desa ekowisata Pampang agar tetap menarik dan dapat mengundang minat wisatawan.

Salah satu desa ekowisata Pampang di Gunung Kidul adalah Desa Ekowisata Pampang yang terletak di Playingan Gunung Kidul. Desa ekowisata ini awalnya terkenal dengan konservasi burung, namun saat ini sudah mengembangkan berbagai inovasi produk wisata 
yang ditawarkan. Saat ini Desa Ekowisata Pampang memiliki beberapa icon yang menarik, diantaranya adalah sebagai daerah konservasi burung, kerajinan perak, river tubing, wisata agro, wisata kuliner jajanan pasar, outbond/fun game, camping ground, upacara adat Rasulan, dan arsitektur rumah tradisional.

Desa Ekowisata Pampang didirikan pada tahun 2017 dengan total pengunjung sebanyak 1400 wisatawan. Hal ini menunjukkan bahwa desa ini harus lebih meningkatkan strategi pemasaran agar dapat meningkatkan jumlah wisatawan. Saat ini desa ekowisata Pampang sedang melakukan pengembangan dengan membuat beberapa fasilitas tambahan agar lebih diminati oleh wisatawan.

Desa ekowisata Pampang memberikan kebebasan bagi masyarakat untuk mengelola pedesaannya sesuai dengan keaslian desa tersebut. Desa ekowisata Pampang termasuk pro-poor tourism yang berdampak pada pengentasan kemiskinan, di mana kegiatan wisata ini dapat menjadi peluang, kesempatan, pemberdayaan, dan ruang partisipasi terhadap pemberdayaan dan akses dan setara bagi kesejahteraan. Oleh karena itu desa ekowisata Pampang sangat berpengaruh pada peningkatan kesejahteraan masyarakat.

Agar desa ekowisata Pampang mampu menghadapi persaingan dengan wilayah lain, maka peran pemerintah sebagai pelaku dan fasilitator dipandang sangat perlu untuk menjamin terlaksananya pembangunan dan pengembangan desa ekowisata Pampang dengan mengikutsertakan dan mengoptimasikan para pelaku pembangunan (stakeholders) di sektor ini, dengan demikian diharapkan tercipta produk wisata yang berdaya saing tinggi.

Berdasarkan uraian di atas, maka sangat menarik untuk dilakukan suatu penelitian dengan tema Strategi Pengembangan desa ekowisata Pampang Gunungkidul untuk Meningkatkan Jumlah Kunjungan Wisatawan.

\subsection{Kajian Pustaka}

\subsubsection{Strategi dan Pengembangan Daya Tarik Wisata}

Pengembangan destinasi pariwisata merupakan perencanaan yang baik dan tepat. Pengembangan tersebut harus menggabungkan beberapa aspek penunjang kesuksesan pariwisata. Aspek-aspek pariwisata tersebut adalah aksesibilutas (transportasi dan saluran pemasaran), karakteristik infrastruktur pariwisata, tingkat interaksi sosial, keterkaitan /kompatibilitas dengan sektor lain, daya tahan akan dampak pariwisata, tingkat resistensi komunitas lokal (Pitana dan Diarta, 2009).

Menurut Sunaryo (2013) berbagai kisi-kisi pemahamam mengenai destinasi pariwisata seperti halnya diadaptasi dari banyak batasan pengertian yang telah diberikan oleh para pakarnya seperti: Cooper, Fletcher, Gilbert, Shepherd dan Wanhill (1998), pada intinya mengandung tujuan yang sama bahwa kerangka pengembangan Destinasi Pariwisata paling tidak harus mencakup komponen-komponen utama sebagai berikut.

1. Objek dan Daya Tarik (Atraction) yang mencakup: daya tarik yang berbasis utama pada kekayaan alam, budaya maupun buatan/artifical, seperti event atau yang sering disebut sebagai minat khusus.

2. Aksesibillitas (Accecibility), yang mencakup dukungan sistem transportasi yang meliputi: rute atau jalur trasnportasi, fasilitas terminal, bandara, pelabuhan dan moda transportasi lain.

3. Amenitas (Amenitas), yang mencakup fasilitas penunjang dan pendukung wisata meliputi: akomodasi, rumah makan, retail, toko cinderamata, fasilitas penukaran uang, dan fasilitas kenyamanan lain.

4. Fasilitas pendukung (Ancillary Service) yaitu ketersediaan fasilitas pendukung yang digunakan oleh wisatawan, seperti bank, telekomunikasi, pos, rumah sakit, dan lain sebagainya.

5. Kelembagaan (Institutions) yaitu terkait dengan keberadaan dan peran masingmasing unsur dalam mendukung terlaksananya kegiatan pariwisata termasuk masyarakat setempat sebagai tuan rumah (host).

Menurut Suwantoro (2004) strategi pengembangan kepariwisataan bertujuan untuk mengembangkan produk dan pelayanan yang berkualitas, seimbang dan bertahap.

Langkah Pokok:

1. Dalam jangka pendek dititik-beratkan pada optimasi, terutama untuk:

a. Mempertajam dan memantapkan citra kepariwisataan;

b. Meningkatkan mutu tenaga kerja;

c. Meningkatkan kemampuan pengelolaan;

d. Memanfaatkan produk yang ada;

e. Memperbesar saham dawi pasar pariwisata yang telah ada.

2. Dalam jangka menengah dititik-beratkan pada konsolidasi, terutama dalam:

a. Memantapkan citra kepariwisataan Indonesia;

b. Mengkonsolidasikan kemampuan pengelolaan;

c. Mengembangkan dan diversifikasi produk;

d. Mengembangkan jumlah dan mutu tenaga kerja

3. Dalam jangka panjang dititik-beratkan pada pengembangan dan penyebaran dalam: 
a. Pengembangan pengelolaan;

b. Pengembangan dan penyebaran produk dan pelayanan;

c. Pengembangan pasar pariwisata baru;

d. Pengembangan mutu dan jumlah tenaga kerja.

Suwantoro (2004) menyebutkan sapta kebijakan pembangunan pariwisata adalah sebagai berikut.

1. Promosi

Promosi pada hakikatnya merupakan pelaksanaan upaya pemasaran. Promosi pariwisata harus dilaksanakan secara selaras dan terpadu, baik dalam negeri maupun luar negeri.

2. Aksesibilitas

Akasesibilitas merupakan salah satu aspek penting yang mendukung pengembangan pariwisata, karena menyangkut pengembangan lintas sektoral

3. Kawasan Pariwisata

Meningkatkan peran serta daerah dan swasta dalam pengembangan pariwisata, memperbesar dampak positif pembangunan dan mempermudah pengendalian dampak lingkungan

4. Produk Wisata

Upaya untuk padat menampilkan produk wisata yang bervariasi dan mempunyai kualitas daya saing yang tinggi.

5. Sumber Daya Manusia

Sumber daya manusia merupakan salah satu modal dasar pengembangan pariwisata.

Berdasarkan hasil penelitian yang dilakukan oleh Barreto dan Giantari (2015) bahwa pengembangan suatu objek wisata dipengaruhi oleh kualitas objek wisata seperti keunikan yang dimiliki, promosi, kualitasn SDM, akses, fasilitas, serta amenitas. Suatu objek wisata dalam meningkatkan nilai kompetitif sehingga mampu bersaing dan bisnis objek wisata yang berkelanjutan. Untuk mengatasiketerbatasan SDM yang profesional maka pemerintah perlu merekrut pegawaipegawai yang memiliki latar belakang pendidikan kepariwisataan. Untuk mengatasi strategis yang berkaitan dengan promosi maka dinas Pariwisata dan Kebudayaan hendaknya mengaktifkan website secara optimal dan menjelaskan didalamnya secara detail tentang daya tarik yang dimiliki suatu objek serta program-program dalam pengembangan objek wisata air panas itu sendiri.

Berdasarkan uraian teori strategi pengembangan kepariwisataan, strategi pengembangan desa wisata dapat dilaksanakan dengan mencakup komponen-komponen sebagai berikut.
1. Meningkatkan objek dan daya tarik wisata sebagai daya tarik utama suatu desa wisata

2. Memperbaiki melengkapi aksesibilitas

3. Memperbaiki dan melengkapi amenitas

4. Menambah fasilitas pendukung

5. Melakukan kegiatan promosi

6. Kualitas SDM

\subsubsection{Konsep Pengembangan Pariwisata} Berkelanjutan

Sejak dilakukan langkah-langkah untuk pengembangan pariwisata di Indonesia, maka kegiatan-kegiatan terencana dan terprogram yang dilakukan oleh pemerintah pada hakeketnya memang bertujuan untuk 'berkelanjutan' khususnya di bidang pariwisata misalnya, apa yang dimaksud dengan pembagunan pariwisata berkelanjutan pada intinya berkelanjutan dengan usaha menjamin agar sumber daya alam, sosial dan budaya yang dimanfaatkan untuk pembagunan pariwisata agar dilestarikan untuk generasi mendatang (Ardika, 2003).

Pariwisata berkelanjutan menurut konsep Muller (1999) adalah pariwisata yang dikelola mengacu pada pertumbuhan kualitatif, maksudnya adalah meningkatkan kesejahteraan, perekonomian dan kesehatan masyarakat. peningkatan kulitas hidup dapat dicapai dengan meminimalkan dampak negatif sumber daya alam yang tidak dapat diperbarui.

Pembangunan pariwisata berkelanjutan (sustainable tourism development) pembangunan pariwisata yang menekankan pada prinsip pembangunan berkelanjutan. WTO (1999), menekankan ada tiga hal penting dalam pembangunan pariwisata berkelanjutan yaitu:

1. Quality. Sustainable tourism provides a quality experience for visitor, while improving the quality of the host community and protecting the quality of environment.

2. Continuity. Sustainable tourism ensures the continuity of the natural resources upon which it based and the continuity ofthe cultural of the host community with satisfying experience for visitors.

3. Balance. Sustainable tourism balances the need of the tourism industry, supporters of environment, and the local community.

\subsection{Metode Penelitian}

Penelitian ini menggunakan pendekatan kualitatif. Penelitian kualitatif terdiri dari suatu rangkaian teknik interpretasi yang akan menjelaskan, mentransformasikan, dan menjelaskan makna, bukan frekuensi, dari suatu kejadian dalam dunia sosial yang kurang lebih terjadi secara alami (Cooper dan Schindler, 2011). Penelitian kualitatif dapat menunjukkan kehidupan masyarakat, sejarah, tingkah laku, fungsionalisasi oraganisasi, pergerakan sosial, 
dan hubungan kekerabatan.Beberapa data dapat diukur dengan melalui data sensus, tetapi analisis data tetap menggunakan kualitatif.

Sumber data pada startegi pengembangan desa ekowisata Pampang Yogyakarta adalah menggunakan data primer dan sekunder. Data primer adalah wawancara mendalam terhadap terhadap pengelola 3 desa ekowisata Pampangguna mendapatkan penjelasan mengenai strategi pengembangan yang telah dilakukan selama ini sehingga dapat menyusun strategi baru yang dapat dikembangkan di desa ekowisata Pampang. Data primer dilakukan dengan pengamatan secara langsung pada 3 desa ekowisata Pampangtersebut. Sedangkan data sekunder diperoleh dari studi kepustakaan atau penelitian terdahuluyang terkait dengan masalah yang akan diteliti. Data dari studi kepustakaan digunakan sebagai data pendukung dari hasil data primer. Data informasi tersebut diperoleh dari jurnal, website, buku, artikel dan studi kepkustakaan yang berhubungan dengan penelitian ini.

Pada penelitian ini akan menggunakan data primer yang diperoleh dengan cara wawancara mendalam/depthinterview. Teknik ini merupakan teknik pengumpulan data yang khas penelitian kualitatif (Ghony dan Almanshur, 2012). Lebih lanjut dinyatakan bahwa cara utama yang dilakukan pada metode kualitatif adalah untuk memahami persepsi, persamaan, dan pengetahuan orang adalah dengan wawancara mendalam atau intensif (Ghony dan Almanshur, 2012).

Pada penelitian ini, peneliti melakukan wawancanera mendalam terhadap pengelola 3 desa wisata. Pada interview peneliti akan menanyakan mengenai strategi pengembangan Comunity Bases Tourism (CBT) dari dinas yang telah diterapkan dan melihat hasilnya. Peneliti juga melakukan wawancara mendalam kepada pengelola desa ekowisata Pampang mengenai dampak pada strategi yang telah diterapkan.

Analisis data pada strategi pengembangan desa ekowisata Pampang di Gunungkidul untuk meningkatkan kunjungan wisatawan dilakukan pada saat di lapangan, yaitu pada saat pengumpulan data berlangsung dan setelah pengumpulan data selesai. Peneliti akan terus melontarkan pertanyaan hingga jawaban narasumber dianggap cukup. Setelah wawancara mendalam pada narasumber, peneliti akan segera melakukan analisis dengan reduksi data, yaitu dengan menyederhanakan jawaban yang diberikan oleh narasumber tersebut. Setelah penyederhanaan dilakukan maka tahap selanjutnya adalah dengan kategorisasi data.Jika data sudah dikategorisasi, maka dilakukan pengkodingan. Setelah dilakukan pengkodingan maka dilakukan penafsiran data kemudian ditarik kesimpulan.

Metode analisis kualitatif yang digunakan adalah metode deskriptif kualitatif. Alat analisis kualitatif dalam penelitian ini menggunakan metode SWOT. Menurut Rangkuti (2005) analisis SWOT merupakan salah satu metode untuk menggambarkan kondisi dan mengevaluasi suatu masalah, proyek atau konsep bisnis yang berdasarkan factor internal (dalam) dan factor eksternal (luar). Hasil dari penafsiran data, maka data akan dianalisis kembali dengan penggunakan SWOT. Pada analisis SWOT tersebut akan terlihat kekuatan, kelemahan, puluang dan ancaman dari ke tiga desa ekowisata Pampangtersebut. Analisis SWOT memiliki fungsi untuk melihat kekuatan, kelemahan, peluang dan ancaman dari 3 desa ekowisata Pampangtersebut sehingga akan terlihat upaya yang harus dilakukan oleh pengelola desa ekowisata Pampangdalam pengembangan desa ekowisata Pampangdi Gunungkidul.

\subsection{Hasil Penelitian Dan Pembahasan}

Desa ekowisata pampang terletak di Kecamata Paliyan Kabupaten Gunung Kidul. Desa Pampang terdiri dari 5 pedukuhan, yaitu Dusun Kedungdowo Kulon, Kedungdowo Wetan, Dusun Pampang, dan dusun Jetis. Desa Ekowisata Pampang baru mulai dirintis tahun 2017, dengan potensi yang dimiliki adalah area pusat konservasi burung, kerajinan perak, river tubing (susur sungai), wisata agro, wisata kuliter serta jajanan pasar, outbond, camping ground, dan uparaca adat Rasulan (bersih desa).

Potensi yang selama ini sudah dimiliki oleh Desa Pampang adalah kerajinan perak. Terdapat lebih daro 100 pengrajin perak di desa ini. Potensi lain yang dimiliki adalah konservasi burung, kuliner tradisional, dan jamu herbal. Kegiatan ekowisata di desa ini menjadi salah satu penggerak di desa ini sehingga menjadi salah satu daya tarik tersendiri bagi wisatawan.

Desa Ekowisata Pampang sudah mulai banyak dikunjungi oleh wisatawan. Hal ini ditunjukkan pada data statistik pada tahun 2017 yaitu 1.441 wisatawan. Desa Ekowisata Pampang masih tergolong baru namun sudah banyak diminati oleh wisatawan. Saat ini desa Pampang terkenal dengan daerah konservasi burung. Selain area pusat konservasi burung, Desa Ekowisata Pampang juga memiliki beberapa icon yang menarik, diantaranya adalah kerajinan perak, river tubing, wisata agro, wisata kuliner jajanan pasar, outbond/fun game, camping ground, upacara ada Rasulan, dan arsitektur rumah tradisional. Namun Desa Pampang masih berupaya melakukan pengembangan-pengembangan potensi yang 
dimilikinya sehingga lebih dapat menarik minat kunjung wisatawan. Potensi wisata yang dimiliki oleh Desa Ekowisata Pampang cukup banyak namun belum dikelola dan dipromosikan dengan baik. Oleh karena itu, promosi desa ekowisata ini harus ditingkatkan lagi agar dapat dikenal oleh masyarakat Indonesia. Hal ini menjadikan Desa Ekowisata Pampang masih membutuhkan strategi pemasaran dan mengangkat potensi yang dimiliki oleh Desa Pampang. Dengan demikian Desa Ekowisata Pampang harus meningkatkan daya tarik wisatanya dengan menggali potensi-potensi wisata yang ada.

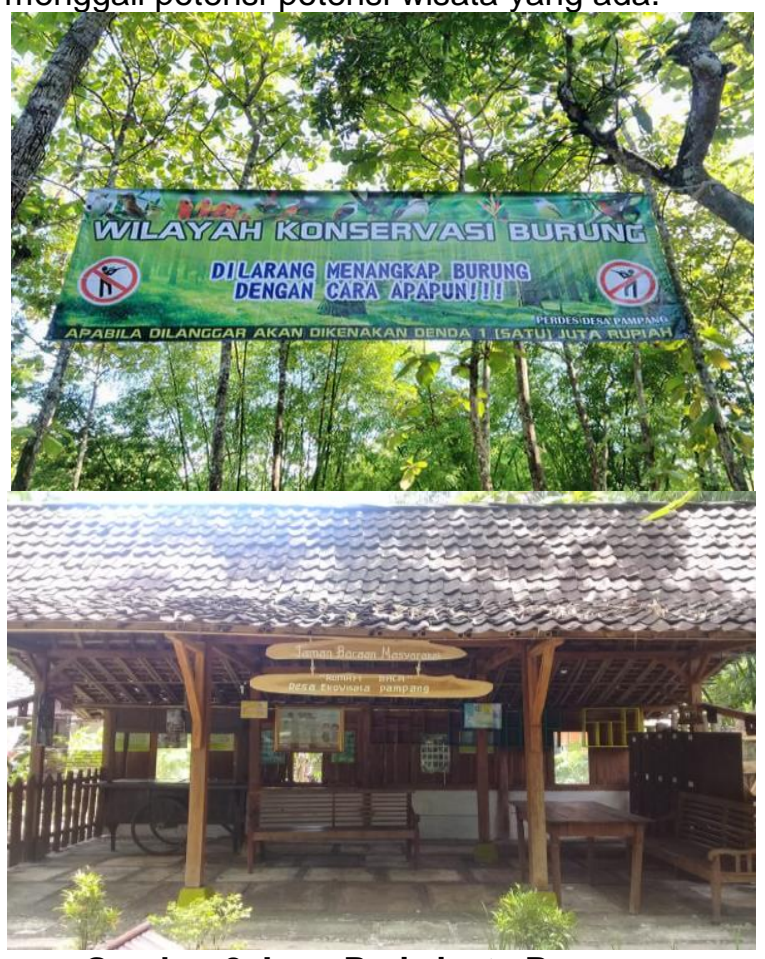

Gambar 8. Icon Pariwisata Pampang

Upaya pengembangan desa ekowisata Pampang berhasil mendapatkan banyak penghargaan, yaitu penghargaan dari Dinas Pariwisata Provinsi Daerah Istimewa Yogyakarta, selain ini mendapatkan juara 2 dari Dinas LIngkungan Hidup, juara 1 lomba kampong hijau di tingkat kabupaten.

Desa Ekowisata Pampang dirintis tahun 2017 sehingga banyak banyak yang perlu dikembangkan untuk menambah jumlah wisatawan yang berkunjung. Adapun salah satu cara untuk mengembangkan desa ekowisata Pampangini adalah dengan analisis SWOT desa Pampang. Adapun analisis SWOT desa ini adalah sebagai berikut.

1. Kekuatan

a. Banyak potensi yang dimiliki oleh desa ekowisata Pampang, yaitu kerajinan perak, koservasi burung, jamu herbal, dan makanan tradisional

b. Memiliki potensi wisata yang berbeda dengan desa ekowisata
Pampanglainnya, yaitu konservasi dan edukasi

c. Memiliki rumah baca (taman bacaan untuk masyarakat dan wisatawan) sehingga untuk wahana menambah wawasan

d. Menawarkan paket atraksi sugai yaitu tubing sungai

e. Masyarakat memiliki kekompakan dalam mengelola desa wisata

f. Paket wisata yang ditawarkan cukup murah, misalahnya paket susur sungai dengan ban dan makan siang hanya $\mathrm{Rp}$ 45.000 jadi harga paket sangat terjangkau

g. Memiliki pengelolaan bank sampah sehingga sampah-sampah dapat dikelola dengan baik.

2. Kelemahan

a. Sarana dan prasarana belum lengkap

b. SDM masih harus banyak dikembangkan dengan mengikuti pelatihan-pelatihan

c. Pemandu wisata belum memiliki lisensi

d. Brosur wisata kurang menarik sehingga harus ada penbaharuan

e. Beberapa paket wisata belum siap dan belum terlaksana, seperti camping ground

\section{Peluang}

a. Memberikan peluang bagi masyarakat untuk bekerja

b. Tidak hanya menawarkan wisata alam tetapi juga menawarkan pket wisata edukasi, jamu herbal dan konservasi sehingga memiliki peluang yang tinggi untuk terus dikembangkan

\section{Ancaman}

a. Ancama desa ekowisata ini adalah
bencana alam gempa bumi yang
merusak rumah

b. Ancaman lain adalah hujan yang mengakibatkan banjir dan angina putting beliung

Berdasarkan analisis SWOT di atas bahwa desa ekowisata Pampang merupakan desa ekowisata yang baru saja dirintis sehingga banyak yang harus dikembangkan. Desa ekowisata ini memliki peluang yang cukup tinggi untuk mengembangkan desa ekowisata Pampang karena paket yang ditawarkan berbeda dengan desa ekowisata Pampanglainnya.

Dampak merupakan akibat, imbas atau pengaruh yang terjadi (baik postif maupun negative) dari sebuah tindakan yang dilakukan oleh suatu kegiatan. Berbagai strategi telah dilakukan untuk pengembangan desa ekowisata Pampang di Gunugkidul sehingga menimbulkan beberapa dampak dari strategi yang telah 
dilakukan. Dampak tersebut antara lain adalah sebagai berikut.

1. Berdasarkan paket wisata yang telah ditawarkan, dampak yang ditimbulkan adalah bertambahnya wisatawan domestik yang berasal dari Yogyakarta dan sekitarnya. Hal ini disebabkan karena promosi yang dilakukan adalah dengan menggunakan dari mulut ke mulut atau disebut "gethuk tular", seingga wisatawan yang datang hanya sekitar Yogyakarta dan sekitarnya.

2. Paket wisata yang ditawarkan monoton dan tiap-tiap desa ekowisata Pampang paket yang ditawarkan sama sehingga tiap-tiap desa ekowisata Pampangberusaha untuk menambah paket wisata. Penambahan paket wisata sangat diperlukan untuk menambah minat kunjung wisatawan serta menambah minat wisatawan untuk berkunjung kembali ke desa wisata.

3. SDM desa ekowisata Pampang dinilai kurang dalam hal keterampilan berbahasa asing sehingga saat ini dilakukan banyak pelatihan-pelatihan untuk pemandu wisata. Hal ini bertujuan untuk menjamu wisatawan asing yang berkunjung ke berbagai desa wisata.

4. Promosi akan terus ditingkatkan, desa ekowisata Pampang di Gunungkidul masih menggunakan promosi dari mulut ke mulut sehingga wisatawan yang datang mayoritas wisatawan domestik yang berasal dari wilayah Yogyakarta dan sekitarnya. Oleh karena itu saat ini tiap-tiap desa ekowisata Pampang berupaya untuk membuat website, blog, instagram, facebook, brosur dan paket wisata yang menarik yang bertujuan untuk menambah jumlah kunjungan wisatawan.

5. Aksesibilitas menuju desa ekowisata Pampang sangat bagus sehingga wisatawan dapat dengan mudah mendatangi lokasi tujuan. Jalan menuju desa ekowisata Pampang sangat bagus sehingga dapat dilalui oleh seluruh jenis kendaraan, seperti motor, mobil, dan bus pariwisata.

6. Minat wisatawan untuk berkunjung kembali masih kurang dikarenakan paket wisata yang ditawarkan kurang beragam. Hal ini berdampak untuk penambahan paket wisata agar jenis wisata beragam.

\subsection{Penutup}

\subsubsection{Kesimpulan}

Strategi yang sudah diterapkan di desa ekowisata Pampang yaitu menawarkan atraksi berupa wisata alam. Sistem promosi yang dilakukan masih manual yaitu dari mulut ke mulut. SDM yang dimiliki kurang dalam berbahasa asing dan kurang menguasai keterampilan namun sudah banyak yang memiliki lisensi sebagai pemandu. Aksesibilitas menuju desa ekowisata Pampangsangat baik sehingga dapat dilalui berbagai kendaraan. Produk wisata yang ditawarkan monoton sehingga desa ekowisata Pampangharus meningkatkan jenis paket wisata agar dapat meningkatkan jumlah wisatawan.

Dampak yang ditimbulkan dari strategi yang sudah dilakukan adalah meningkatnya jumlah wisatawan domestik, namun hanya berasal dari Jogja dan sekitarnya. Terbatasnya pelayanan terhadap wisatawan asing. Peningkatan dalam pembuatan paket wisata.

\subsubsection{Saran}

Berdasarkan kesimpulan di atas, maka saran yang dapat diberikan untuk meningkatkan jumlah kunjungan wisatawan adalah:

1. Menambah jenis-jenis paket wisata dan membuat brosur wisata yang menarik sehingga dapat menambah jumlah kunjungan wisatawan dan dapat menambah minat wisatawan datang kembali.

2. Memberikan pelatihan pada pengelola desa ekowisata Pampangterutama untuk pemandu wisata. Pelatihan diutamakan adalah pelatihan bahasa asing karena untuk pelayanan dan komunikasi pada wisatawan asing.

3. Membuat strategi untuk mengajasi atau menagantisipasi bencana alam terutama banjir dan longsor.

\section{Daftar Pustaka}

[1] Ardika, I Gde, I .2003. "Pariwisata Budaya Berkelanjutan Suatu Refleksi danHarapan" dalam Pariwisata Budaya Berkelanjutan: Refleksi danHarapan di Tengah Perkembangan Global. Denpasar: KajianPariwisata Program Pascasarjana Universitas Udayana.

[2] Barreto, Mario. dan Giantari I.G.A Ketut. 2015. "Strategi Pengembangan Objek Wisata Air Panas Di Desa Marobo, Kabupaten Bobonaro, Timor Leste". E-Jurnal Ekonomi dan Bisnis Universitas Udayana.Vol. 4.11.hal. 773-796.

[3] Cooper, D. R., dan Schindler, P. S. 2011. Business Research Methods.Singapore: The McGraw-Hill Companies, Inc.

[4] Cooper, Fletcher, Gilbert, Shepherd dan Wanhill. 1998. Tourism Principles and Practices. England: Longman Group Limited.

[5] Ghony, Djunaidi dan Fauzan Almanshur. 2012. Metodologi Penelitian Kuaitatif. Yogyakarta: Ar-Ruzz Media.

[6] Muller, T. 1999. The Common Reflection Surface Stack Seismic Imaging without 
Explicit Knowledge of The Velocity Model. Der Andere Verlag, Bad lburg.

[7] Pitana, I Gde.dan Surya Diarta, I Ketut. 2009. Pengantar IImu Pariwisata. Yogyakarta : Penerbit Andi.

[8] Rangkuti, Feddy. 2005. Analisis SWOT: Teknik Membedah Kasus Bisnis. Jakarta: PT. Gramedia
[9] Sunaryo, Bambang. 2013. Kebijakan Pembangunan Destinasi Pariwisata Konsep dan Aplikasinya Indonesia. Yogyakarta: Gava Media.

[10] Suwantoro, Gamal. 2004. Dasar-Dasar Pariwisata. Yogyakarta: Andi.

[11] World Tourism Organization (WTO). 1999. International Tourism A Global Perspective. Madrid: Spain. 